\title{
Impact of Spatial, Thermal and Lighting Parameters on the Efficiency and Comfort of Users in Indian Workspaces
}

\author{
Pooja M. Pathak ${ }^{1}$, Alpana R. Dongre ${ }^{1} \&$ Jyoti P. Shiwalkar ${ }^{2}$ \\ ${ }^{1}$ Department of Architecture and Planning, VNIT, Nagpur, India \\ ${ }^{2}$ Department of Statistics, Hislop College, Nagpur, India \\ Corrospondence: Pooja M. Pathak, 57, Sunderban Layout, Gayatri, Narendra Nagar, Nagpur, Maharashtra, India. \\ Tel: 91-712-93-7167-4304.E-mail:pathakpooja19@yahoo.in
}

\author{
Received: May 15, 2014 Accepted: June 4, 2014 Online Published: July 31, 2014 \\ doi:10.5539/jsd.v7n4p111 URL: http://dx.doi.org/10.5539/jsd.v7n4p111
}

\begin{abstract}
Providing comfortable indoor environment in workspaces is one of the prime concerns for better results in occupant's performance. The indoor environmental factors in workplaces should follow functional as well as behavioural requirements. The occupant's needs and opinions are the guiding factors to achieve good workspace designs, where the physical conditions influence their well-being and indirectly influence the work output of their employer's business performance. The paper reports the results from an empirical study of fifteen randomly selected offices from the city of Nagpur, India having hot and dry climatic conditions covering three seasons (winter, summer, rainy). The paper aims at revealing the association/correlation between five functional parameters as spatial, furniture, thermal, lighting and acoustics and their behavioural impact on the occupants through a quantitative and qualitative analysis. Quantitative is the pooled average scores of ambient temperature, relative humidity, air velocity and illuminance levels on every work plane measured in three seasons separately. Qualitative is the pooled average scores of the opinions of the occupants based on the questionnaire administered in the summer season related to five parameters. One Way ANOVA is used to check whether the average scores assigned to the various architectural parameters by the employees of companies vary significantly. For qualitative data, Yule's coefficient of association is used to investigate an association between users' perception, comfort, performance and satisfaction levels about lighting and illuminance levels measured in all three seasons. Correlation analysis is carried out to obtain linear correlation between the subjective variables and the measured values of components of air and thermal parameter in three seasons. It also evaluates the user's subjective opinions related to parameters leading to efficiency and comfort and suggests preferential parameters. This shall give an insight to designers while planning workspaces in similar conditions. The evaluation of user's subjective opinions related to the parameters leading to efficiency and comfort has shown that spatial arrangement, lighting and thermal are the prime factors due to which efficiency and comfort get enhanced in indoor environments.
\end{abstract}

Keywords: workspaces, functional, behavioural, quantitative, qualitative, spatial, thermal, lighting, comfort

\section{Introduction}

Comfort and performance standards in the workspaces have become a primary concern in India recently and hence there is a remarkable change in designing strategies adopted for the same. The end users of such spaces are the occupants who are spending major time in these spaces and therefore the indoor environmental factors in workplaces should follow functional as well as behavioural requirements. Presently there is no clear cut demarcation as working or non-working hours, the concept of working environment is progressively shifting towards better comfortable situations and increased performance is assumed to be the result of good workplace environment. The environmental aspects include physiological, sociological and psychological comfort. The parameters encompassing these three are- spatial arrangement, furniture and ergonomics, air and thermal, lighting and acoustics. It implies that the employees need environmental support for performing the activities leading to positive physiological and psychological impact and improved performances. The paper aims at investigating a correlation if any of workspace designs and its impact on the users, through a quantitative and qualitative analysis of various parameters. It also tries to establish the preferences stated by occupants in terms of parameters to achieve satisfaction, comfort and efficiency of the selected workspaces.

The literature in this field has discussed various methodologies, contexts and parameters and the methodologies 
adopted are based either on quantitative, qualitative or experimental research strategies. User's perception about various aspects of environment shall give better justification if correlated with physical measurements. Functional comfort and related behavioural responses if assessed quantitatively and qualitatively will result in better environmental conditions and work output. A similar study is done for employees in a bank wherein the workspace design, layout, furniture, noise, air quality are given equal importance to examine the relationship between workspace physical conditions and employees productivity (Leblebici, 2012). Another study is done in Malaysia's office building as Post-Occupancy Evaluation based on qualitative survey related to thermal comfort, air movement noise and cleanliness. The outcome of the survey is visual comfort; indoor air movement and ventilation constitute the highest factor in terms of occupant's comfort ability (Natasha Khalil, 2009).

The paper presents an empirical study and quantitative and qualitative analysis of spatial as functional and related behavioural parameters of fifteen selected office spaces with three different densities of working population. The workspaces are located in Nagpur, $2^{\text {nd }}$ Capital of the State of Maharashtra, India, centrally located and characterized by hot and dry climate. The selected office spaces are distributed in various areas of the city as commercial, residential or mixed land use as commercial/residential. The study is conducted in three season's winter, summer and rainy.

The objectives of the study are-

- To determine occupant's comfort, performance, satisfaction and perception levels by investigating and establishing association if any (positive/negative) between subjective and objective variables.

1) For lighting as a parameter

2) For air and thermal parameter

- To evaluate the users' subjective opinion related to the parameters leading to efficiency and comfort and aspects that lead to their enhancement.

- To determine the preferences for the physical and psychological parameters based on the subjective opinions given by the occupants for achieving comfort and efficiency with a-

1) Group wise (sample size) comparison within the selected fifteen offices.

2) Type wise comparison within the selected fifteen offices.

- To suggest preferential parameters as per users' choice to be considered while planning workspaces in similar context.

\subsection{About the Selected Workspaces}

Workplace selection is made from city of Nagpur and are a part of administrative offices dealing with paper, coal, IT services, sale and purchase, food products, chartered accountancy, export- import and news agency, having sample size up to 25,26 to 50 and 51 to 100 (Table 1). They are again categorized as ten administrative, three IT Companies and two CA Companies. The study is based on physiological, sociological and psychological comfort criteria; the focus being on the impact of functional and behavioural parameters on the performance of the occupants. The evaluation done is on the basis of quantitative and qualitative data collected related to above mentioned parameters for all the fifteen offices. A general description with existing physical conditions is included about the offices. The commonalities in the selected fifteen offices are-

- All the selected offices are designed for the purpose and have a frame structure construction.

- The spatial arrangement comprises of a mixed type- combination of cabins, cubicles and open workstations.

- The offices are facilitated with a combination of custom made and modular furniture with adjustable seating arrangement. Material used is reconstituted wood, laminate and glass.

- Lighting condition is a result of a combination of natural and artificial lighting.

- Air and thermal conditions are a result of combination of natural and air-cooling/air-conditioning. 
Table 1. General description about selected offices

\begin{tabular}{|c|c|c|c|c|c|c|c|c|c|}
\hline Sr. No. & $\begin{array}{l}\text { Case } \\
\text { Study }\end{array}$ & Orientation & Type & $\begin{array}{l}\text { Sample } \\
\text { Size }\end{array}$ & $\begin{array}{l}\text { Area } \\
\text { of } \\
\text { office } \\
\text { Sq.Mt. }\end{array}$ & $\begin{array}{l}\text { Density Sq. } \\
\text { Mt./person }\end{array}$ & $\begin{array}{l}\text { Ratio of } \\
\text { cabins/workstations }\end{array}$ & $\begin{array}{l}\text { Independent } \\
\text { building }\end{array}$ & $\begin{array}{l}\text { Floor } \\
\text { occupying } \\
\text { a space in } \\
\text { building }\end{array}$ \\
\hline 1 & $\begin{array}{l}\text { Jain } \\
\text { House }\end{array}$ & North -South & Paper & 11 & 190 & 15 & $46 \%-54 \%$ & $\sqrt{ }$ & \\
\hline 2 & $\begin{array}{l}\text { Jain } \\
\text { House }\end{array}$ & North -South & Coal & 13 & 190 & 15 & $46 \%-54 \%$ & $\sqrt{ }$ & \\
\hline 3 & $\begin{array}{l}\text { I.T. } \\
\text { Company }\end{array}$ & North -South & I.T. & 15 & 160 & 10 & $8 \%-90 \%$ & & $\sqrt{ }$ \\
\hline 4 & Automak & North -South & Manufacture & 16 & 150 & 9 & $25 \%-75 \%$ & & $\sqrt{ }$ \\
\hline 5 & $\begin{array}{l}\text { Regards } \\
\text { Solutions }\end{array}$ & East- West & I.T. & 24 & 99 & 4 & $4 \%-96 \%$ & & $\sqrt{ }$ \\
\hline 6 & $\begin{array}{l}\text { Sagdeo } \\
\text { and Co. }\end{array}$ & East-West & C.A. & 32 & 246 & 7.6 & $22 \%-78 \%$ & & $\sqrt{ }$ \\
\hline 7 & $\begin{array}{l}\text { Jawade } \\
\text { and } \\
\text { Kaware }\end{array}$ & North -South & Designing & 34 & 325 & 9.5 & $12 \%-88 \%$ & $\sqrt{ }$ & \\
\hline 8 & $\begin{array}{l}\text { Anand } \\
\text { Trading }\end{array}$ & North -South & Sale & 35 & 297 & 8.5 & $18 \%-82 \%$ & $\sqrt{ }$ & \\
\hline 9 & $\begin{array}{l}\text { Rasoya } \\
\text { Protiens }\end{array}$ & North -South & $\begin{array}{l}\text { Food } \\
\text { Products }\end{array}$ & 35 & 295 & 8.4 & $20 \%-80 \%$ & $\sqrt{ }$ & \\
\hline 10 & $\begin{array}{l}\text { Demble } \\
\text { and } \\
\text { Ramani }\end{array}$ & East- West & C.A. & 50 & 425 & 7.5 & $10 \%-90 \%$ & & $\sqrt{ }$ \\
\hline 11 & $\begin{array}{l}\text { Solar } \\
\text { Industries }\end{array}$ & East- West & Manufacture & 60 & 460 & 7.7 & $16 \%-84 \%$ & $\sqrt{ }$ & \\
\hline 12 & $\begin{array}{l}\text { Gupta } \\
\text { Energy }\end{array}$ & North -South & Power & 70 & 960 & 13 & $5 \%-95 \%$ & & $\sqrt{ }$ \\
\hline 13 & Infocepts & East- West & I.T. & 90 & 760 & 8.3 & $7 \%-93 \%$ & $\sqrt{ }$ & \\
\hline 14 & Gammon & East- West & Manufacture & 90 & 1370 & 15 & $10 \%-90 \%$ & $\sqrt{ }$ & \\
\hline 15 & $\begin{array}{l}\text { Dainik } \\
\text { Bhaskar }\end{array}$ & North -South & News & 100 & 1497 & 12 & $10 \%-90 \%$ & $\sqrt{ }$ & \\
\hline
\end{tabular}

\subsection{Climatic Environment of Nagpur and Meteorological Conditions during the Survey}

The climate of Nagpur city is characterized by hot and dry climate. The well-distributed rainfall in the rainy season and dryness follows a typical seasonal weather pattern. The cold season is from December to February and is followed by the hot season from March to May. The southwest monsoon season is from June to September while the period October-November constitutes the post-monsoon season. May is the hottest month with the mean daily maximum temperature at $42.7^{\circ} \mathrm{C}\left(108.8^{\circ} \mathrm{F}\right)$ which may even reach up to $48^{\circ} \mathrm{c}$ (Nagpur, 2000).

\section{Materials}

The 'Environmental Psychology' is a well addressed issue in western countries, USA and Europe and implies an interface between human behaviour and socio-physical environment (Wikipedia, 2010). This study focuses on 
the enquiry regarding how people experience environmental psychology of workspace. This issue is substantially handled in western countries related to workspace design and its impact on comfort and efficiency of the users; however in Indian conditions it is significantly neglected. This is observed through the literature study done in similar context. The study involves independent variables as measured values of ambient temperature, air velocity, relative humidity, lux levels and surface temperatures. The dependent variables are subjective opinions of the occupants. The study corresponds to the category of Correlation Research strategy with the Dichotomous framework employing the terms quantitative and qualitative analysis. A similar kind of an approach has been adopted in Abbottabad, Pakistan, wherein 21 bank branches are surveyed. Here subjective data is collected for five parameters as spatial, furniture, temperature, noise and lighting for productivity (Ameena Hamid, 2009). A quantitative and qualitative analysis is done in Australia for air and thermal comfort of university students using drawing classes. The measurements were taken of temperature, air velocity and humidity (Christhina, 2010). Jacquline C. Vischer in her paper 'Towards an Environmental Psychology of Workspace: How People are affected by Environments for Work' has emphasized upon individual, group and organizational survey for office workers leading to efficiency, comfort, accuracy, speed and errorlessness (Vischer, 2008).

The instruments used to measure ambient temperature, air velocity, relative humidity, lux levels is 4 in 1 environment tester of Lutron make, LM 8000, Anemometer, Hygrometer, Thermometer and Lux meter, ISO 9001, quality management system certified by SGS. Operating temperature is $0^{\circ} \mathrm{C}$ to $80^{\circ} \mathrm{C}$, operating air velocity is $0.4 \mathrm{~m} / \mathrm{sec}$ to $30 \mathrm{~m}$. $/ \mathrm{sec}$., operating humidity is Max $80 \% \mathrm{RH}$ and light is 0 to $2200 \mathrm{lux}$. Non contact infrared thermometer is used for measuring surface temperature. This is a non touch measure by infrared. The temperature range is: $-30^{\circ} \mathrm{C}$ to $550^{\circ} \mathrm{C}$ and manufactured by MEXTECH DT- 8811 .

Illuminance levels recommended by various global and Indian standards namely IESNA (Illuminating Engineers of North America) (IESNA, 2000), CIBSE (Chartered Institution of Building Services Engineers) (CIBSE, 2005), BEE (Bureau of Energy Efficiency). (BEE, 2006), India, IS3646 (I.3 1992), India and European Norm for the lighting of workspaces ranges between 300 to 500 lux for occupants working on VDT (Visual Display Terminals). Indoor Temperatures, air velocity and humidity recommended by global standards by CIBSE Guide A Environmental design, London (CIBSE, 2005) is, for winter :- $21^{\circ} \mathrm{C}$ to $23^{\circ} \mathrm{C}$, summer:- $22^{\circ} \mathrm{C}$ to $24^{\circ} \mathrm{C}$, $0.15 \mathrm{~m} / \mathrm{sec}$ and $50 \% \mathrm{RH}$ for all seasons. Inside design conditions as per section 4.4 .3 of section 3, air conditioning, heating and mechanical ventilation by Indian standards of NBC (National Building Code) 2005 is, for winter: $-21^{\circ} \mathrm{C}$ to $23^{\circ} \mathrm{C}$ with $\mathrm{RH} 50 \%$ to $60 \%$, summer:- $25^{\circ} \mathrm{C}$ to $26^{\circ} \mathrm{C}$ with $\mathrm{RH}$ less than $40 \%, 0.19 \mathrm{~m} / \mathrm{sec}$ respectively (NBC, 2005).

Statistical analysis is performed on the acquired data. At the outset one way ANOVA is performed for group wise comparison of quantitative scores obtained on the architectural parameters under study. Minitab 13 is used for calculating the Confidence Interval for true percentage of employees giving preferences for parameters. Yule's Coefficient of Association is used between user's comfort, perception, performance and satisfaction related to lighting and the actual type of lighting provided in the workspaces. Karl Pearson's Correlation coefficient is used to study correlation between the objective and subjective variables related to air and thermal components.

\section{Method}

The spatial planning in selected offices constitutes of Private (cabins), Semiprivate (cubicles) and open plan workstations. The occupants in three categories are -up to 25,26 to 50 and 51 to 100 and the sample size is 450 in no. Three season's winter, summer and rainy are covered for quantitative survey wherein the selected offices are visited for six to eight days in rotation in every season. The physical parameters are measured with an interval of two hours in office timings (10am to 6pm).

Qualitative survey is conducted with the help of a five-pointer questionnaire (45 questions) concerning their perception about these workspaces. Questions are related to above said parameters and to understand how office users experience present day environment and their preferences for better conditions. The questions focused on appropriateness of seating location, sufficiency of space, crowding versus privacy, visual and physical connectivity, seating arrangement regarding spatial planning. Flexibility of furniture, space for storage and display, height ratio of table to chair, posture, type of seating, accessibility to ancillary activities, height of partition, layout of furniture are asked related to furniture and ergonomics. Air and Thermal parameter covered the aspects as thermal comfort on seating, opinion on preferred location, preference for natural ventilation over mechanical, and operation of windows, adaptability with change of clothing, and physical control on temperature. There are questions focused on preference for natural light, control on light, sufficiency of illuminance levels for working, concentration due to task lighting, strain and fatigue due to lighting conditions, position of windows for day light and period of the day with higher concentration levels due to lighting. Regarding acoustics, the 
questions are based on disturbance due to external noise, trouble in audible levels due to office layout, disturbance due to machinery and adjoining discussions.

Apart from the usual demographic questions (age, gender, height and weight), the questions also pointed towards their perception about the efficiency in work, enhancement of efficiency and comfort during prime working hours with preferred conditions. The subjects are observed in three seasons and selected occupants are interviewed once, adding to the qualitative survey of the workspaces. All the questions are leading to the enhancement of comfort and efficiency levels of occupants for better output.

Statistical analysis on the acquired data is performed to accomplish the objectives. As a part of qualitative data analysis, average scores of subjective opinions on all the parameters are calculated for every office from the responses of informants on a five point questionnaire. Quantitative data analysis for each office included the pooled average scores of the measured data for ambient temperature, air velocity, relative humidity, lighting levels and surface temperatures in the three seasons. Lux levels of offices in three seasons are computed for categorizing levels as per standards and levels below standards.

The analysis is performed in two parts. Group wise average scores are compared on the five parameters by first dividing the companies in 3 groups according to their size (No. of employees/ work spaces) and then dividing the companies in to 3 types, based on the type of work done in the company. One Way ANOVA is used to check whether the average scores assigned to the various architectural parameters by the employees of companies vary significantly.

Next, the analysis of user's opinion on the parameters related to efficiency and comfort is conducted to identify the preferences given for the parameters to be used at the planning stage. This has given an insight about subject's opinions of preferred parameters for achieving comfort and efficiency. Minitab has been used as an analytical tool. The Confidence Interval for the true percentage of employees giving preferences for each parameter is constructed. Also, the correlation analysis is carried out to obtain linear correlation between the subjective variables and the measured values of components of air and thermal parameter in three seasons. The significance of the observed correlations is tested using t-test.

\section{Results}

As mentioned in the objectives and Method a Quantitative and Qualitative approach is adopted to get an empirical report of existing conditions about the five parameters in the selected fifteen offices. The research questions posed resulted in a set of responses, identifying how the occupants have given preferences for the physical and psychological parameters for achieving comfort and efficiency.

The first objective stated has given a subjective parameter study of group wise comparison of offices. Group I (up to 25 users), Group II (26 to 50 users) and Group III (51 to 100 users), having five offices in each group.

\subsection{Analysis of Group Wise Subjective Parameter Study}

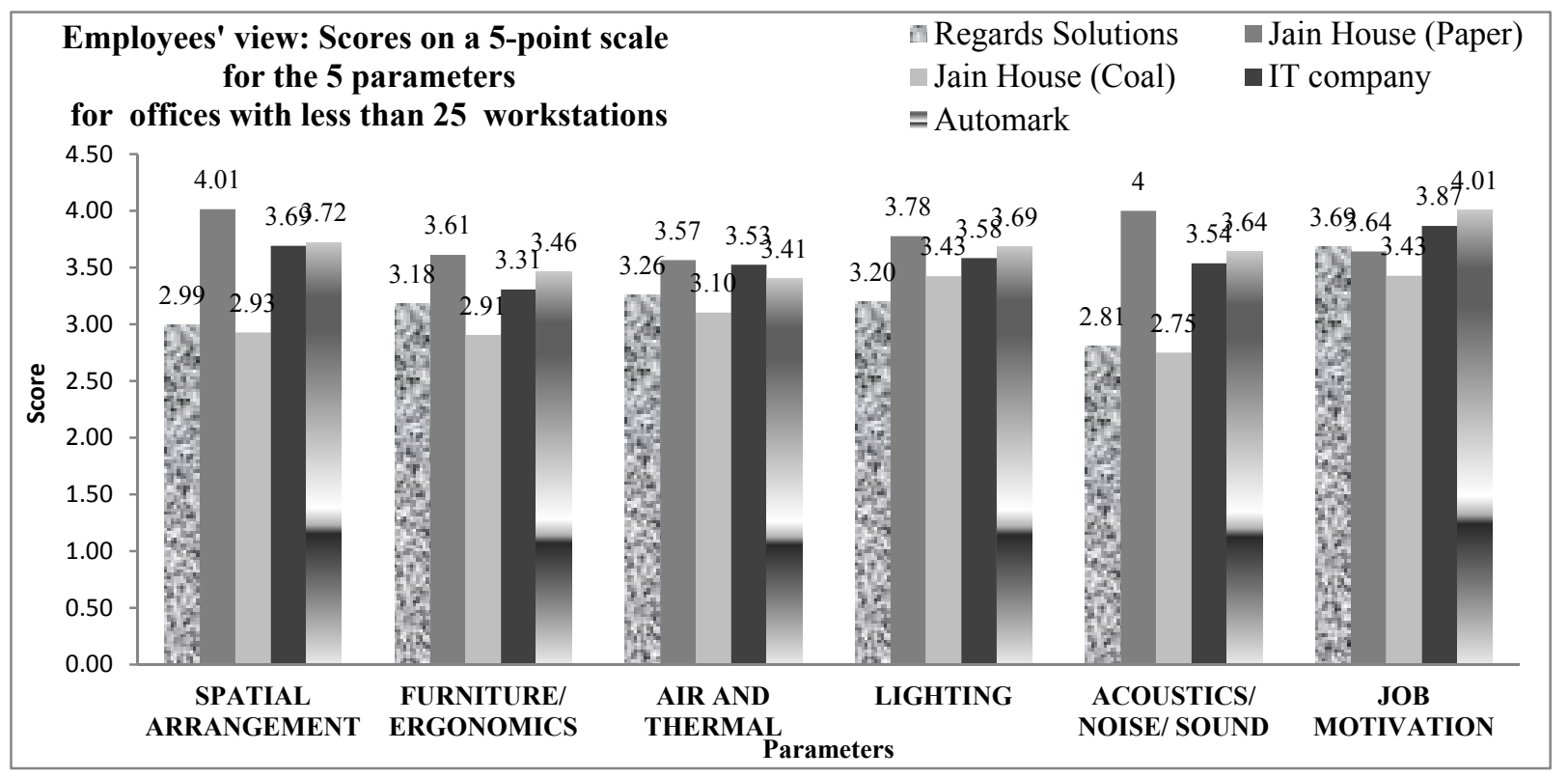

Figure 1. Employees' view on a five point scale for group I offices 
OBSERVATIONS: The rating on a five point scale given by the occupants related to five parameters indicate that, employees of Jain House (paper) rated their office high on a 5-point scale on spatial arrangement and Acoustics (with an average score $4 \&$ more) (Figure 1). Also, the ratings (scores) on Furniture/ Ergonomics, Air and thermal and Lighting for this company are seen relatively on a higher side than the other four companies.

The next best ratings on the 5 parameters of architectural study are received by the I. T. Company and Automark Company. Regards solutions and Jain coal received relatively low rating on spatial arrangement and Acoustics/ noise/ sound (with a score less than 3 ) by their employees.

So, to check whether the average scores assigned by the employees of Group-I (less than 25 workstations) companies on the 5 parameter vary significantly, One-way ANOVA is carried out (Table 2).

The following hypothesis is tested:

$\mathbf{H}_{\mathbf{0}}$ : There is no significant difference in the average scores on a 5-point scale on the 5 parameters Spatial arrangement, Furniture/ Ergonomics, Air and thermal, Lighting and Acoustics/ noise/ sound for the companies in group $-\mathrm{I}$.

Against

$\mathbf{H}_{1}$ : The average scores on a 5-point scale on the 5 parameters under study for group -I companies differ significantly.

The output of One-way ANOVA using MS- Excel is presented below:

Table 2. Summary and one way ANOVA

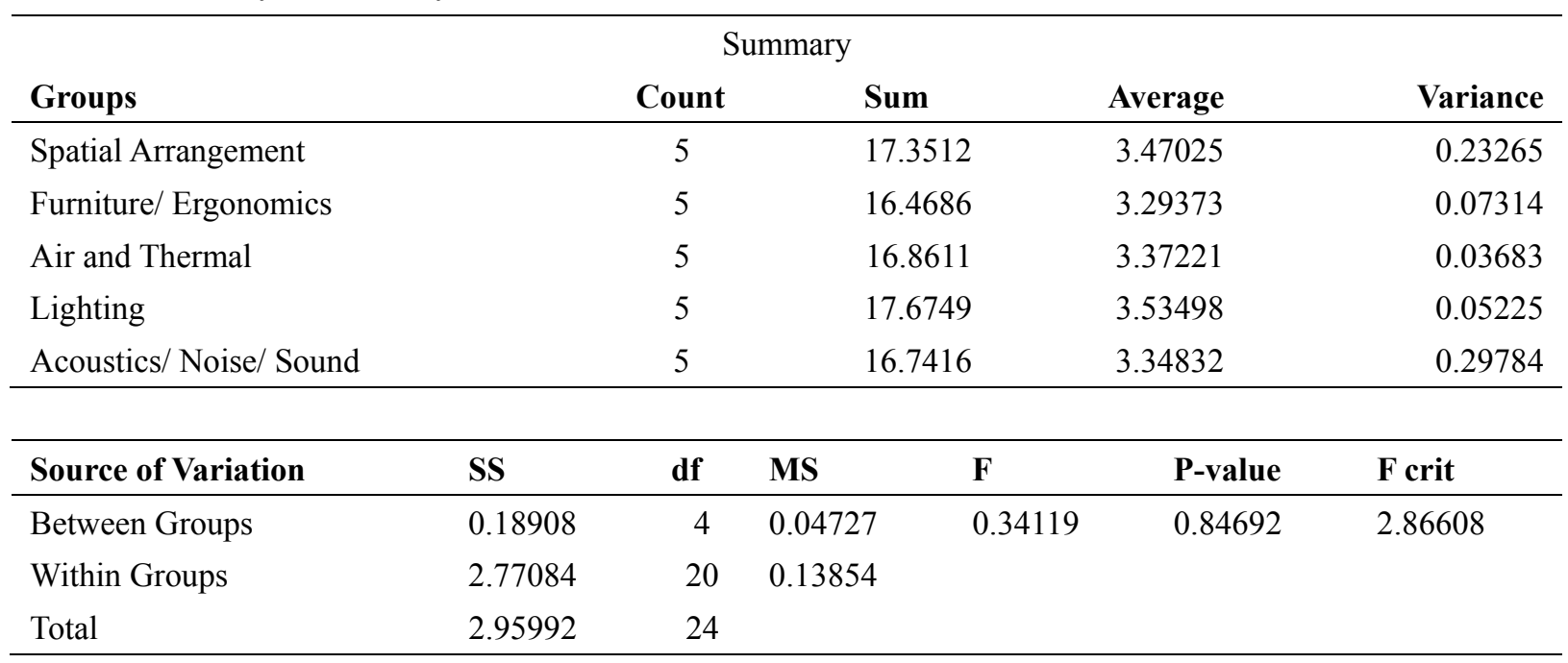

Since the p-value of the F-Test in the ANOVA table is greater than 0.05 , we fail to reject the null hypotheses $\mathrm{H}_{0}$ at $5 \%$ level of significance and conclude the following:

In the companies with up to 25 workstations, the parameter wise average scores on a 5-point scale do not differ significantly ( $p$-value $=0.8469$ ). In other words, the opinions of users in the companies with 'up to 25 workstations' match in rating the architectural parameters under study.

Similar analysis is carried for the companies in group-II (26 to 50 users) and Group III (51 to 100 users). The following are the results of one-way ANOVA

- In the companies with 26 to 50 workstations, the parameter wise average scores on a 5-point scale do not differ significantly ( $\mathrm{p}$-value $=0.1238$ ).

- Also, in the companies with 51 to 100 workstations, the parameter wise average scores on a 5-point scale do not differ significantly ( $\mathrm{p}$-value $=0.0698)$

\subsection{Study of Architectural Parameters According to Type of Offices}

There are 3 categories of offices according to the type of work done in the offices, namely, Type-I Administrative office, Type-II IT Company and Type-III CA firm. 
Type-I Administrative office: There are 10 offices under administrative category. Parameter wise scores on a 5-point scale for these offices are given in the following table (Table 3).

Table 3. Parameter wise average scores on a 5-point scale for administrative type offices

\begin{tabular}{ccccccccccc}
\hline Factor & $\begin{array}{c}\text { Jain House } \\
\text { (Paper) }\end{array}$ & $\begin{array}{c}\text { Jain House } \\
\text { (Coal) }\end{array}$ & $\begin{array}{c}\text { Auto } \\
\text { mark }\end{array}$ & $\begin{array}{c}\text { Kaware } \\
\text { Jawade }\end{array}$ & $\begin{array}{c}\text { Rasoya } \\
\text { Proteins }\end{array}$ & $\begin{array}{c}\text { Anand } \\
\text { Trading }\end{array}$ & $\begin{array}{c}\text { Solar } \\
\text { office }\end{array}$ & $\begin{array}{c}\text { Gupta } \\
\text { Energy }\end{array}$ & $\begin{array}{c}\text { Dainik } \\
\text { Bhaskar }\end{array}$ & $\begin{array}{c}\text { Gammo } \\
\text { n India }\end{array}$ \\
\hline $\begin{array}{c}\text { Spatial } \\
\text { Arrangement } \\
\text { Furniture/ }\end{array}$ & 4.01 & 2.93 & 3.72 & 3.19 & 3.34 & 3.59 & 3.53 & 3.68 & 3.95 & 3.35 \\
$\begin{array}{c}\text { Ergonomics } \\
\text { Air and }\end{array}$ & 3.61 & 2.91 & 3.46 & 2.92 & 3.06 & 3.42 & 3.35 & 3.55 & 3.39 & 3.11 \\
$\begin{array}{c}\text { Thermal } \\
\text { Lighting }\end{array}$ & 3.57 & 3.1 & 3.41 & 3.53 & 3.37 & 3.49 & 3.29 & 3.19 & 3.28 & 3.24 \\
$\begin{array}{c}\text { Acoustics/ } \\
\text { Noise/ Sound }\end{array}$ & 3.78 & 3.43 & 3.69 & 3.51 & 3.69 & 3.85 & 3.89 & 3.57 & 3.47 & 3.53 \\
\hline
\end{tabular}

One-way ANOVA is carried out to test whether there is any significant difference in the average scores on the 5 architectural parameters under study for the administrative type companies (Table 4). The output using MS-Excel is given below:

Table 4. Summary and one-way ANOVA output

\begin{tabular}{lllll}
\hline & \multicolumn{2}{c}{ Summary } & & \\
Groups & Count & Sum & Average & Variance \\
\hline Spatial Arrangement & 10 & 35.3000 & 3.5300 & 0.1138 \\
Furniture/ Ergonomics & 10 & 32.7818 & 3.2782 & 0.0671 \\
Air and Thermal & 10 & 33.4595 & 3.3460 & 0.0234 \\
Lighting & 10 & 36.4088 & 3.6409 & 0.0272 \\
Acoustics/ Noise/ Sound & 10 & 35.0300 & 3.5030 & 0.1326 \\
\hline
\end{tabular}

\begin{tabular}{lllllll}
\hline \multicolumn{7}{c}{ One way ANOVA-table } \\
Source of Variation & SS & df & MS & F & P-value & F crit \\
\hline Between Groups & 0.8553 & 4 & 0.2138 & 2.9376 & 0.0306 & 2.5787 \\
Within Groups & 3.2756 & 45 & 0.0728 & & & \\
Total & 4.1309 & 49 & & & \\
\hline
\end{tabular}

Since the p-value of the F-test is smaller than 0.05 , we fail to accept the null hypothesis of equality of parameter wise average scores of administrative type companies at $5 \%$ level of significance and conclude the following:

The administrative type companies differ significantly in their parameter wise average scores. In other words, the opinions of the users of the administrative type companies differ in rating the architectural parameters under study. This may be because in administrative offices, the parameters Furniture/ Ergonomics and Air \& Thermal may be overlooked as compared to the other 3 architectural parameters and hence these two parameters received relatively low average scores as compared to other 3 parameters.

Similar analysis is carried out for the type-II and type-III companies and the results are as follows:

- There is no significant difference in the parameter wise average scores of IT type companies at $5 \%$ level of significance ( $p$-value 0.946). In other words, the opinions of the users of the IT type companies match significantly in rating the architectural parameters under study. The conclusion indicates that the IT companies are found to be homogeneous in meeting the requirements of all the architectural parameters. 
- Also, there is no significant difference in the parameter wise average scores of the CA companies on the 5 parameters under study. $(\mathrm{P}$-value $=0.1424)$. This indicates that the CA firms are also homogeneous in meeting the requirements of almost all the architectural parameters under study.

\subsection{Analysis of User's Opinion on Parameters Related to Efficiency and Comfort}

In the 15 offices under study, the opinions of the sampled employees are collected through a questionnaire. The responses of the informants are scrutinized and summarized in the form of the following table (Table 5). As given in the objective, the users' subjective opinions related to the parameters leading to efficiency and comfort are evaluated.

Table 5. Users' subjective opinions related to the parameters leading to efficiency and comfort

\begin{tabular}{|c|c|c|c|c|c|c|}
\hline \multirow[t]{2}{*}{ Office name } & \multicolumn{6}{|c|}{$\begin{array}{l}\text { Number of respondents giving opinion on - important aspect due to which } \\
\text { Efficiency and comfort levels get enhanced }\end{array}$} \\
\hline & $\begin{array}{l}\text { Spatial } \\
\text { arrangement }\end{array}$ & Thermal & Furniture & Lighting & Ventilation & $\begin{array}{l}\text { Total no. } \\
\text { respondents }\end{array}$ \\
\hline Jain House & 4 & 1 & 2 & 2 & 1 & 10 \\
\hline Jain House & 4 & 1 & 1 & 2 & & 8 \\
\hline I.T. Company & 5 & 6 & 1 & 1 & & 13 \\
\hline Automak & 6 & 1 & 3 & 5 & 1 & 16 \\
\hline RegardSolutions & 1 & 10 & 1 & 8 & & 20 \\
\hline Sagdeo and Co. & 1 & 10 & 6 & 7 & 7 & 31 \\
\hline Jawade Kaware & 10 & 3 & 3 & 13 & 4 & 33 \\
\hline Anand Trading & 7 & 7 & & 12 & 4 & 30 \\
\hline Rasoya Protiens & 5 & 2 & 1 & 4 & 5 & 17 \\
\hline Demble Ramani & 18 & 4 & 5 & 5 & 8 & 30 \\
\hline Solar Industries & 26 & 3 & 1 & 7 & 9 & 47 \\
\hline Gupta Energy & 10 & 7 & 2 & 6 & 6 & 31 \\
\hline Infocepts & 7 & 14 & 2 & 16 & 11 & 50 \\
\hline Gammon & 18 & 26 & 3 & 17 & 16 & 80 \\
\hline Dainik Bhaskar & 5 & 4 & & 8 & 4 & 21 \\
\hline $\begin{array}{l}\text { Total no. of } \\
\text { respondents }\end{array}$ & 127 & 99 & 31 & 113 & 76 & 437 \\
\hline
\end{tabular}

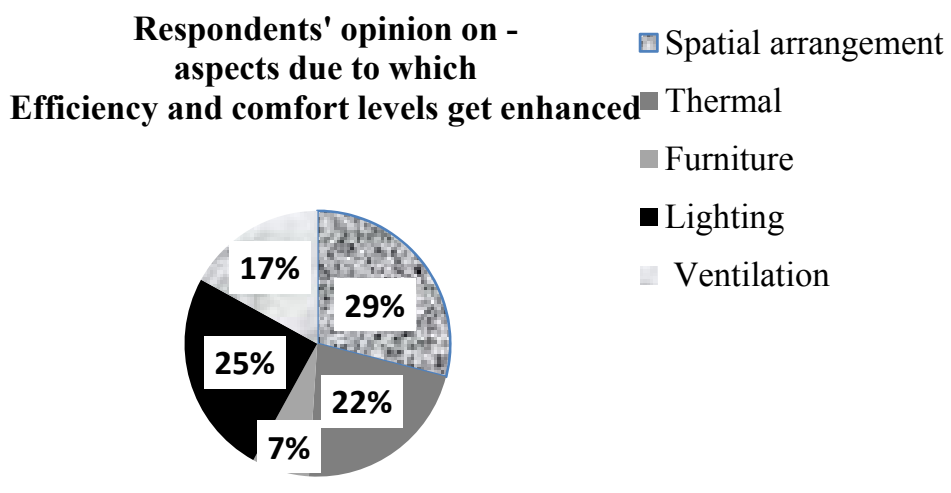

Figure 2. Respondents' opinions due to which efficiency and comfort levels are enhanced 
From the above diagram it is seen that, $29 \%$ of the sampled employees opined that the prime aspect due to which efficiency and comfort get enhanced is spatial arrangement. Corresponding percentages are $25 \%$ for lighting and $22 \%$ for Thermal (Figure 2). Thus, according to $76 \%$ of the sampled employees the spatial arrangement, lighting and thermal are the prime factors due to which efficiency and comfort get enhanced.

So, to find the true proportion of respondents in such type of offices in the region, who opine that the spatial arrangement, lighting and thermal are the important aspects due to which efficiency and comfort get enhanced, we calculated $95 \%$ confidence interval using the sample proportion 0.76 and the sample size 437 .

Using Minitab 13, the $95 \%$ Confidence Interval for the true percentage of employees in such type of offices in Nagpur region, who feel that Spatial arrangement, Lighting and Thermal are important aspects due to which efficiency and comfort get enhanced, is obtained as $(73.37 \%, 81.4 \%)$.

\subsection{Association between Offices Based on Average Score on Lighting and their Observed Lux Levels}

One of the objectives of the survey was to establish an association if any (positive/negative) between user's visual comfort, performance, satisfaction and perception about lighting levels and the measured Lux levels in 15 offices in the three seasons. A general description along with the existing lighting condition is given about the offices with Case study 1 to 5 having sample size as 0 to 25, Case study 6 to 10 having sample size as 26 to 50 and Case study 11 to 15 having sample size as 51 to 100 (Table 6).

Table 6. General description about selected offices and their lighting conditions

\begin{tabular}{|c|c|c|c|c|c|c|c|c|c|}
\hline \multirow{2}{*}{$\begin{array}{l}\text { Sr. } \\
\text { No. }\end{array}$} & \multirow[t]{2}{*}{ Case Study } & \multirow[t]{2}{*}{ Orientation } & \multirow[t]{2}{*}{ Type } & \multirow{2}{*}{$\begin{array}{l}\text { Sample } \\
\text { Size }\end{array}$} & \multirow{2}{*}{$\begin{array}{l}\text { Area } \\
\text { office } \\
\text { Mt. }\end{array}$} & \multirow{2}{*}{$\begin{array}{l}\text { of } \\
\text { Sq. }\end{array}$} & \multirow{2}{*}{$\begin{array}{l}\text { Overall Density } \\
\text { Sq. Mt./person }\end{array}$} & \multicolumn{2}{|c|}{ Lighting conditions } \\
\hline & & & & & & & & Electric & Mixed \\
\hline 1 & Jain House & North -South & Paper & 11 & 190 & & 15 & - & $\sqrt{ }$ \\
\hline 2 & Jain House & North -South & Coal & 13 & 190 & & 15 & - & $\sqrt{ }$ \\
\hline 3 & I.T. Company & North -South & I.T. & 15 & 160 & & 10 & $\sqrt{ }$ & \\
\hline 4 & Automak & North -South & Manufacture & 16 & 150 & & 9 & - & $\checkmark$ \\
\hline 5 & $\begin{array}{l}\text { Regards } \\
\text { Solutions }\end{array}$ & East- West & I.T. & 24 & 99 & & 4 & $\sqrt{ }$ & - \\
\hline 6 & $\begin{array}{l}\text { Sagdeo and } \\
\text { Co. }\end{array}$ & East-West & C.A. & 32 & 246 & & 7.6 & - & 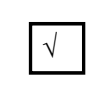 \\
\hline 7 & $\begin{array}{l}\text { Jawade and } \\
\text { Kaware }\end{array}$ & North -South & Designing & 34 & 325 & & 9.5 & - & $\sqrt{ }$ \\
\hline 8 & $\begin{array}{l}\text { Anand } \\
\text { Trading }\end{array}$ & North -South & Sale & 35 & 297 & & 8.5 & - & $\sqrt{ }$ \\
\hline 9 & $\begin{array}{l}\text { Rasoya } \\
\text { Protiens }\end{array}$ & North -South & Food Products & 35 & 295 & & 8.4 & $\sqrt{ }$ & - \\
\hline 10 & $\begin{array}{l}\text { Demble and } \\
\text { Ramani }\end{array}$ & East- West & C.A. & 50 & 425 & & 7.5 & $\sqrt{ }$ & - \\
\hline 11 & $\begin{array}{l}\text { Solar } \\
\text { Industries }\end{array}$ & East- West & Manufacture & 60 & 460 & & 7.7 & - & $\sqrt{ }$ \\
\hline 12 & $\begin{array}{l}\text { Gupta } \\
\text { Energy }\end{array}$ & North -South & Power & 70 & 960 & & 13 & $\sqrt{ }$ & - \\
\hline 13 & Infocepts & East- West & I.T. & 90 & 760 & & 8.3 & $\sqrt{ }$ & - \\
\hline 14 & Gammon & East- West & Manufacture & 90 & 1370 & & 15 & $\sqrt{ }$ & - \\
\hline 15 & $\begin{array}{l}\text { Dainik } \\
\text { Bhaskar }\end{array}$ & North -South & News & 100 & 1497 & & 12 & - & $\sqrt{ }$ \\
\hline
\end{tabular}

Tabulation for higher and lower level lighting levels is given as under. 
Table 7. Classification of offices based on average score on lighting and observed average Lux levels

Level of comfort, performance, satisfaction and perception

Number of offices with the observed Average Lux level

Higher (A)

Better Lux levels(B)

Lower Lux levels $(\beta)$

Lower $(\alpha)$

4 (AB)

$7(\mathrm{~A} \beta)$

$1(\alpha \mathrm{B})$

$3(\alpha \beta)$

Total number of companies

5

10

In table 7, $A=$ Number of offices with average score on lighting $>3.5, \alpha=$ Number of offices with average score on lighting $\leq 3.5, B=$ Number of offices with observed Lux level 200 and above, $\beta=$ Number of offices with observed Lux level below 200.

To establish whether there is any association if any (positive/negative) between better Lux level (More than 200) and higher satisfaction / comfort level (average score on lighting assigned by the employees greater than 3.5 on a 5-point scale) of employees of 15 offices under study, the Yule's Coefficient of association is calculated.

Applying Yule's coefficient of association $=\mathrm{Q}=\frac{(A B)(\alpha \beta)-(A \beta)(\alpha B)}{(A B)(\alpha \beta)+(A \beta)(\alpha B)}=\frac{(12-7)}{(12+7)}=0.263$

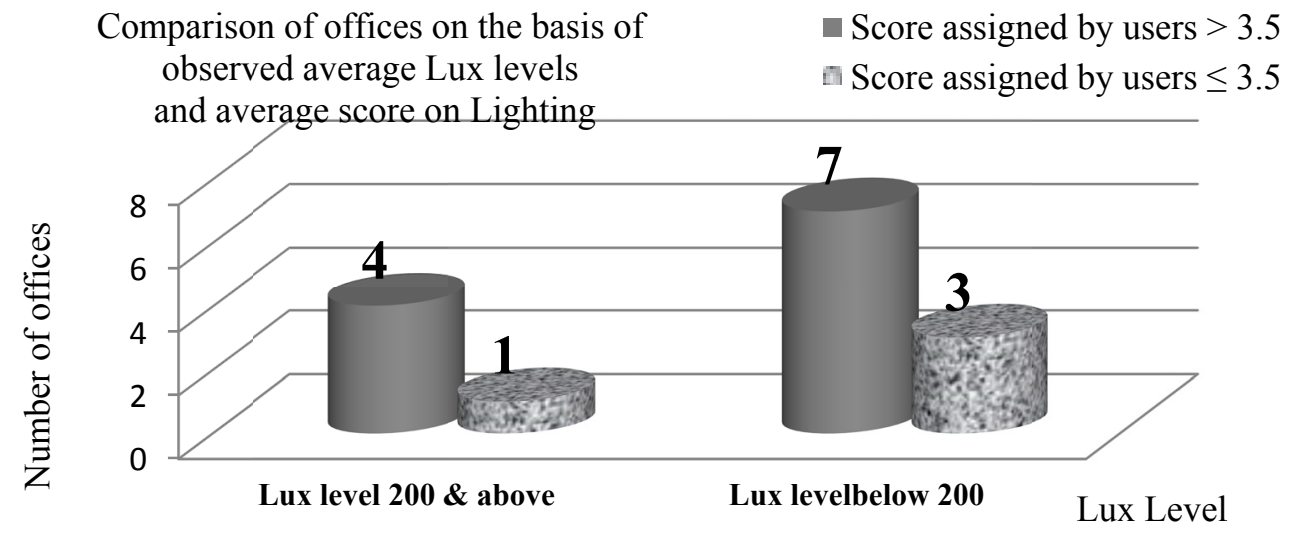

Figure 3. Comparison on the basis of average Lux levels score on lighting

The result show that that even though it is a low degree, there is a positive association between high observed Lux level (above 200lux) in the office and higher satisfaction about lighting related to Visual comfort, performance, satisfaction and perception about lighting expressed by the employees ( Figure 3)._

\subsection{Correlation between Offices based on Average Score on Air and Thermal and their Observed Levels}

As per the objective stated, analysis is done to establish correlation (positive/negative) if any, between the occupants' perception levels in terms of air and thermal parameter as a qualitative measure and the observed pooled average temperatures in summer and winter, pooled average humidity and air velocity in rainy season, pooled average surface temperatures in winter, summer and rainy season as quantitative measurements.

The scores on a 5-point scale on questions related to Air and thermal parameter are converted to average score on air and thermal component $(\mathrm{Y})$ for each of the offices. Then correlation between paired values of $\mathrm{Y}$ and every quantitative variable per office is obtained using Karl Pearson's correlation coefficient. The significance of the observed sample correlation is tested using t-test. The Pearsonian correlation coefficient, calculated value of $\mathrm{t}$-statistic and the p-values of the t-test are presented in the table 8 .

Pooled average temperature in rainy season though taken is not considered in correlation analysis as much variation is not seen compared to winter and summer temperatures. 
Table 8. Pearsonian correlation coefficients between Y: the average score on air \& thermal and other components of air and thermal parameters

\begin{tabular}{|c|c|c|c|c|c|c|c|c|}
\hline \multirow[t]{4}{*}{ Office } & \multirow{4}{*}{$\begin{array}{l}\text { Average } \\
\text { temp. } \\
\text { summer }\end{array}$} & \multirow{4}{*}{$\begin{array}{l}\text { Average } \\
\text { temp. in } \\
\text { winter }\end{array}$} & \multirow{4}{*}{$\begin{array}{l}\text { Average } \\
\text { relative } \\
\text { humidity } \\
\text { in rainy } \\
\text { season }\end{array}$} & \multirow{4}{*}{$\begin{array}{c}\text { Mean } \\
\text { air } \\
\text { velocity } \\
\text { in Rainy } \\
\text { season }\end{array}$} & \multirow{4}{*}{$\begin{array}{l}\text { Mean } \\
\text { s.t in } \\
\text { Winter }\end{array}$} & \multirow{4}{*}{$\begin{array}{l}\text { mean } \\
\text { s.t. in } \\
\text { Summer }\end{array}$} & \multirow{4}{*}{$\begin{array}{l}\text { Mean } \\
\text { s/t. in } \\
\text { Rainy } \\
\text { season }\end{array}$} & \multirow{4}{*}{$\begin{array}{l}\text { (Y) } \\
\text { Average } \\
\text { score on } \\
\text { Air \& } \\
\text { Thermal }\end{array}$} \\
\hline & & & & & & & & \\
\hline & & & & & & & & \\
\hline & & & & & & & & \\
\hline Jain House (Paper) & 28.62 & 28.97 & 75.19 & 0.47 & 31.86 & 33.23 & 30.66 & 3.57 \\
\hline Jain House (Coal) & 30.96 & 30.13 & 66.55 & 0.35 & 34.23 & 34.822 & 31.03 & 3.1 \\
\hline I.T. Company & 27.424 & 27.48 & 67.57 & 0.67 & 28.65 & 29.05 & 30.09 & 3.53 \\
\hline Automak & 29.91 & 26.34 & 73.2 & 0.37 & 27.96 & 32.36 & 28.92 & 3.41 \\
\hline Regards Solutions & 28.4 & 27.61 & 72.15 & 0.32 & 29.12 & 30.43 & 30.7 & 3.26 \\
\hline Sagdeo and Co. & 28.98 & 23.95 & 76.95 & 0.28 & 24.56 & 33.11 & 30.4 & 3.54 \\
\hline Jawade and Kaware & 27.06 & 22.76 & 84.74 & 0.49 & 23.63 & 29.03 & 28.32 & 3.53 \\
\hline Anand Trading & 27.1 & 25.86 & 70.81 & 0.4 & 26.43 & 34.45 & 30.98 & 3.49 \\
\hline Demble and Ramani & 28.05 & 27.14 & 70.45 & 0.57 & 29.2 & 29.98 & 29.72 & 3.28 \\
\hline Solar Industries & 29.4 & 26.036 & 78.4 & 1.178 & 26.36 & 30.92 & 30.48 & 3.29 \\
\hline Gupta Energy & 27.61 & 28.52 & 69.32 & 0.56 & 30.18 & 28.73 & 28.51 & 3.19 \\
\hline Infocepts & 26.49 & 26.59 & 47.56 & 0.44 & 27.57 & 28.16 & 28.79 & 3.14 \\
\hline Gammon & 28.01 & 26.59 & 63.83 & 0.24 & 28.6 & 27.67 & 26.77 & 3.24 \\
\hline $\begin{array}{l}\text { Pearsonian Correlation } \\
\text { coefficients }\end{array}$ & -0.1795 & -0.4889 & 0.6007 & -0.003 & -0.47 & 0.257 & 0.207 & \\
\hline calculated value of t-statistic & -0.6052 & -1.8592 & 2.4920 & -0.001 & -1.77 & 0.881 & 0.701 & \\
\hline $\begin{array}{l}\text { p-value of the t-test for } \\
\text { significance of } \text { sample } \\
\text { correlation }\end{array}$ & 0.5573 & 0.0899 & 0.0299 & 0.9923 & 0.104 & 0.397 & 0.498 & \\
\hline
\end{tabular}

In the above table, if the p-value of the t-test for testing the significance of sample correlation is less than 0.05 then we reject insignificance and accept the claim of significance of sample correlation or else (i.e. if p-value is greater than or equal to 0.05 ) we accept the insignificance of sample correlation. It is observed that,

There exists a significant moderate degree positive linear correlation between the average score on air \& thermal and average relative humidity in rainy season (p-value 0.0299). Other linear correlations are found to be insignificant at $5 \%$ level of significance.

\section{Discussion}

The paper has investigated and presented report on the qualitative data i.e. the responses of the occupants and quantitative data on measurements of components related to architectural parameters under study. The occupants have given rating for architectural and related behavioral parameters on a five point scale.

A categorical and inferential analysis of the scores obtained on a 5-point scale on 5 architectural parameters is carried out. This analysis is based on the opinions of the employees selected from the fifteen offices in Indian context. It has reported about the psychological and physiological impact of parameters on the users leading to comfort and efficiency. The offices are first categorized group wise according to their size (number of employees / workstations) and then according to the type of work (Administrative, IT companies and CA firms).

Jain House (paper) from Group I have given high rating for all the parameters as compared to other companies. The next best ratings on the 5 parameters of architectural study are received by I T Company, Automark from Group I, Sagdeo and Associates, Demble and Ramani and Anand Trading from group II and Solar office and Gupta Energy from Group III. 
The reasons attributed are low density occupancy ( 8 to 15 sq.mt/person), less crowding, location and space provided for seating is satisfactory, and interaction levels are high, lighting levels above 200 lux.

Other offices have given moderate rating on five parameters. Offices like Jawade and Kaware and Rasoya Proteins have given low rating on spatial, furniture and air and thermal parameters. Here the reasons might beAlthough the occupancy density is low, the users are not satisfied with location and space availability for seating and storage. Low rating on all the parameters is shown by Jain (coal), Regards Solutions and Infocepts. The lighting levels are low (below 100lux) in the offices and density is high in two offices giving crowding effect and less privacy.

One-way ANOVA results for testing whether there is any significant difference in the parameter wise average scores given by employees of the companies in the various groups studied as per the sizes are as follows:

- In the companies with less than 25 workstations, 26 to 50 workstations and 51 to 100 workstations, the parameter wise average scores on a 5-point scale do not differ significantly.

However, when we divide the 15 companies according to the type of work done in the office in to 3 types, (administrative, IT type and CA firms) and carry out one way ANOVA for testing whether there is any significant difference in the parameter wise average scores given by employees of the companies within the group, we found that,

- The administrative type companies differ significantly in their parameter wise average scores (p-value 0.03 ). This may be because in administrative offices, the parameters Furniture/ Ergonomics and Air \& Thermal may be overlooked as compared to the other 3 architectural parameters and hence these two parameters received relatively low average scores as compared to other 3 parameters.

- However, there is no significant difference in the parameter wise average scores on a 5-point scale assigned by the employees in IT type companies and CA firms. (P values $>0.05$ ). It indicates that, in IT companies and CA firms there may be homogeneity with respect to the norms of 5 architectural parameters related to work spaces. Hence, the opinions of the users of these types of companies match in rating the architectural parameters under study.

It is observed that, the parameters spatial arrangement, lighting and thermal would receive prime importance from at least $73 \%$ and at the most $81.5 \%$ users in similar set up offices in the region. So, from architectural point of view, architects should concentrate more on these parameters from the point of view of user's comfort, satisfaction and efficiency.

There is a low degree positive association found between high observed Lux level in the office and higher satisfaction about lighting related to Visual comfort, performance, satisfaction and perception about lighting expressed by the employees. However, it is surprising to observe that in only 5 out 15 offices, on an average the observed lighting level is recorded 200 lux and above (required as per the architectural norms), where as in the remaining 10 offices it was recorded less than 200 in all the 3 seasons.

The occupants have given third preference for air and thermal parameter from the efficiency and comfort point of view. However, the linear correlations between average scores on air and thermal parameter and pooled average temperatures in winter and summer, average air velocity in rainy season and pooled average surface temperatures in all the three seasons are found to be insignificant ( $\mathrm{p}$-value for t-test is $>0.05$ ). Reasons attributed may be temperature levels inside the offices are high as compared to the standards prescribed and the occupants are accustomed to the existing situations hence satisfied about IEQ due to adaptability.

Only the moderate degree positive linear correlation between average score on air $\&$ thermal and average relative humidity in rainy season is found significant at $5 \%$ level of significance. (P-value 0. 0299).

\section{Conclusions}

- The empirical report and analysis of categorical data of fifteen selected offices in Indian context has shown that the Architectural parameters as spatial arrangement, lighting, air and thermal, furniture and acoustics play a significant role in achieving comfort, satisfaction and enhancing efficiency of the occupants in a preferential sequence and irrespective of the sample size.

- Group wise comparison: The opinions of the occupants match in rating the architectural parameters under study for the offices irrespective of their sample size.

- Type wise comparison: Parameter wise average scores of administrative type offices differ significantly. There is no significant difference in parameter wise average scores of IT and CA offices. The IT and CA offices are found to be homogeneously meeting the requirements of users with respect to all the parameters. 
- The occupants in the offices (C.I.as 73\%, 78.5\%) may be of the opinion that spatial arrangement, lighting and air and thermal are most prime architectural factors for enhancing efficiency and comfort.

- Comfort, performance, satisfaction levels about lighting expressed by the occupants is supported by low degree positive association between high observed illuminance levels and good rating on this parameter.

- There is a positive linear correlation between pooled average values of relative humidity and air velocity in rainy season, indicates that the occupants are reducing the discomfort due to high humid conditions by using artificial air component.

\section{References}

Ameena Hamid, S. A. (2009). Impact of office design on emplytoees productivity: A case study of banking organizations of Abbotabad Pakistan. Journal of Public Affairs and Administration, 1-13.

Authority, T. I. (2000). Illuminating engineering society of North America. New York: IESNA.

Christhina Candido, R. D. (2010). Cooling exposure in hot humid climates: are occupants addicted? Architectural Science Review, 59-64.

Efficiency, B. O. (2006). BEE Code Lighting. Vadodara - 390007. Devki Energy Consultancy Pvt. Ltd.

I. 3. (1992). Indian standard code of practice for Interior Illumination. New Delhi: Bureau of Indian Standard.

Leblebici, D. (2012). Impact of workspace quality on employees' productivity:case study of a bank in Turkey. Journal of Business, Economics and Finance, 1(1), 38-49.

LG7, S. O. (2005). Lighting guide CIBSE 07. London.

Linda Groat, D. W. (2000). Architectural Research Methods. Canada: John Wiley and Sons.

Nagpur, N. V. (2000). Development Control Regulations - 2000 Nagpur City. Nagpur.

Natasha Khalil, H. N. (2009). Post occupancy evaluation towards indoor environment improvement in Malasia's office building. Journal of sustainable development, 2(1), 186-191.

Vischer, J. (2008). Towards an Environmental Psychology of Workspace: How people are affected by Environment of workspace. Architectural Science Review, 97-108. http://dx.doi.org/10.3763/asre.2008.5114

Wikipedia. (2010, July 23). Environmental psychology, History. Retrieved from the Free Encyclopedia.

\section{Copyrights}

Copyright for this article is retained by the author(s), with first publication rights granted to the journal.

This is an open-access article distributed under the terms and conditions of the Creative Commons Attribution license (http://creativecommons.org/licenses/by/3.0/). 